\title{
A QUEEN FOR ALL SEASONS: ZENOBIA OF PALMYRA ${ }^{1}$
}

\author{
M M Breytenbach (Stellenbosch University)
}

\begin{abstract}
Throughout the centuries a number of truly remarkable women emerged to awe the world. One of these is a charismatic warrior queen of antiquity, Zenobia, last ruler of the once wealthy and exotic city-state of Palmyra in Syria, that flourished in the late Roman Empire of the third century AD. She rose to power upon the death of her husband Odenathus, a client-king of Rome, when she acted as regent for their son Vaballathus ${ }^{2}$ born in $260 \mathrm{AD}$. The queen was just and capable, a patron of artists and philosophers, learned, strong-willed and dynamic, and reputed to be one of the great beauties of history. She fought alongside her troops and astounded the ancient world by carving out a large territory beyond Palmyra, even subjugating Egypt, before being overthrown by the formidable Emperor Aurelian who came to power in $270 \mathrm{AD}$. At his triumph in Rome, Aurelian displayed the Palmyrene queen weighed down by gold chains and jewels, but so great was his respect for her that according to one tradition he settled her in Rome where she lived out the rest of her life.
\end{abstract}

\section{Introduction}

One of the greatest warrior queens of antiquity, Zenobia of Palmyra, stunned the ancient world by her temerity in challenging the powerful Roman Empire in the turbulent third century AD. During her extraordinary career she managed to conquer a great deal of territory over which Rome claimed sovereignty and by 271/2 AD she had created a virtually independent kingdom.

The threat that Zenobia constituted is described as follows (Grant 1981:282):

"[The] most vigorous, durable and menacing of the oriental dissidents came from the oasis city of Palmyra (Tadmor) on the borders between Syria and Mesopotamia”.

In this turbulent time, when Roman hegemony was being threatened from all sides, Zenobia took advantage of the Emperor Claudius Gothicus' preoccupation with the menace of the Goths to extend her power over most of Asia Minor, and then Egypt.

She was not born a ruler, but rose to prominence as the wife of the powerful Odenathus of Palmyra, a client king of Rome. It was after his death, when she was ruling as regent for her son, that she dared to display imperialist ambitions herself.

The proud tradition of semi-legendary queens whose ranks Zenobia joined, include Semiramis of Assyria, Nitocris of Egypt, Cleopatra VII of Egypt, whose influence was also feared by the Romans, and finally the Syrian aristocrat Julia Domna, who married Emperor Septimius Severus.

In the male-dominated and chauvinistic Roman world of the third century AD, Zenobia was seen as an alien who transgressed sexual and political boundaries by assuming power and ruling her city-state, Palmyra, like a man. Rome interacted with the ancient Near East on many levels, culturally, commercially and militarily, but it usually dealt with male rulers. Nevertheless, when the queen of Palmyra succeeded her client-king husband to rule over this

$1 \quad$ This article is based on M M Breytenbach's MPhil thesis in Ancient Studies (University of Stellenbosch) entitled “Queen Zenobia of Palmyra's Rebellion Against Rome”.

2 Other versions of "Vaballath" are "Vaballathus" and in Palmyrene "Wahballath". In Palmyrene Zenobia was "Bath-Zabbai”. 
colourful and exotic centre of Near Eastern civilization, an oasis which dominated the lucrative trans-desert trade route across Syria and Mesopotamia, it prospered under her rule, which means that she was as capable of good governance as any benevolent male ruler.

Her Roman adversary, Aurelian, who would effectively end her run of power, grudgingly conceded that she had ruled very ably but no Roman emperor dared allow such a competitor to prevail.

\section{Sources}

The earliest surviving source, apart from contemporary inscriptions and coins, of most of the events in Zenobia's history is the Historia Augusta. Although Syme (1983:27) describes this as a valuable source of reference, he is of the opinion that this collection supposedly written by six historians (of the six names the most relevant for this study are "Trebellius Pollio" [on Claudius] and "Flavius Vopiscus" [on Aurelian]) was written by a single person during the reign of Theodosius after $395 \mathrm{AD}$, long after the events took place and long after the supposed date of composition. Syme (1983:12) further says: "The larger part of the HA is fabrication.” He (1983:105) also maintains: “Characters from the author's own time may also be suspected" such as "Nicomachus" who supposedly wrote about the correspondence between Zenobia and Aurelian (HA Aurelian 27.6). Unfortunately, one is compelled to glean most of the information about the historical figures dealt with in this study from the Historia Augusta since "For the years $117-284$ it is the sole Latin source of any compass" (Syme (1983:12).

Drinkwater (1999:262) in his review of Watson's Aurelian and the Third Century says: "I suspect that Watson's heroization of Aurelian derives much from the 'Life' of this emperor in the Historia Augusta; and this raises another problem. The HA provides by far the largest ancient narrative that we have on Aurelian. A few, very few, of its statements may be true, but most of what it says in Rabelaisian rubbish... The evidence of the $H A$, however enticing, should be struck from the record."

Another important source is the Greek history of Zosimus ((trans.) Ridley:1982) who, in the sixth century, wrote a history of the Roman Empire from Augustus to 410 AD. Almost nothing is known about this author. His work corroborates the events described in the Historia Augusta.

The progress of Zenobia's rule is seen on coins issued at the time. In the Roman Empire there were 22 mints which were mostly located in the East (Stoneman (1994:117). As she and her son(s) extended their empire to the west, they issued coins struck at Roman mints. At first Zenobia issued coins with the head of the Roman Emperor Claudius Gothicus. After he and his brother and successor both died in 270AD, Zenobia issued coins with Aurelian on the reverse and her son Vaballathus on the obverse. Soon after, in Egypt, there was an Alexandrian issue of the same but this time the legend was in Greek whereas the previous one had been in Latin. Another bronze issue in Alexandria shows the prince and Aurelian face to face. Before Aurelian conquered Palmyra in 272AD, there were two more issues from Syria and Egypt. One shows Vaballathus, calling him Augustus, and on its reverse is Zenobia as Augusta. Vaballathus is "associated with Victory, Hercules, the sun and other impressive deities”, Zenobia with Juno, Artemis, Providence and Hope. Palmyra fell to the Romans soon after (Colledge 1976:234). 
The Palmyrenes' assumption of the highest Roman ruling title, constituted a great challenge and perilous provocation.

Stoneman (1994:119) makes the point that Zenobia only coined in her own name in Egypt "from whose rulers she claimed descent, and where queens were a regular feature", for in fact she was supposed to be secondary to her son in a "male-dominated ancient world".

\section{Historical background to Zenobia’s rule}

Syria, in which Palmyra was located, was invaded over centuries by waves of Egyptians, Babylonians, Hittites, Assyrians, Greeks, Persians and Romans. Alexander the Great of Macedon conquered the area in 331 BC. Until 636 AD the Greeks, the Romans and the Byzantines were the masters of the land. The Hellenistic influence was strong in the ancient Near East for centuries after Alexander's conquests.

Cross-cultural contacts in Syria brought about a Greco-Roman-Syrian mixture. Palmyra was cosmopolitan, so that the gods of various cultures were worshipped (Hitti 1959:59). Palmyrenes mostly spoke Aramaic and Greek (Birley 1988:71). The official languages were Palmyrene and Greek (Millar 1971:5).

While Septimius Odenathus lived he "held the balance of the East in his hand", for had the Palmyrene ruler not come to its aid, the Roman Empire might not have survived there. Consequently Emperor Gallienus conferred on him the titles dux Romanorum and restitutor totius Orientis (Stoneman 1994:106). After he had returned from his second and final victory at Ctesiphon in Persia, he attended a birthday celebration at Emesa, where he was murdered in the year 267 AD by his cousin Maeonius. His son Herodes was murdered as well. The twelfth century writer Zonaras (12. 24 (PL 633) cited by Stoneman (1994:108)) alleged that Maeonius bore Odenathus a grudge after a hunting quarrel. The HA (Tyr. Trig., 27. 2-3) mentions a conspiracy:

"It is said, however, that previously he [Maeonius] had entered into a conspiracy with Zenobia, who could not bear that her stepson Herodes should be called a prince in a higher rank than her own two sons, Herennianus and Timolaus. But Maeonius, too, was a filthy fellow, and so, after being saluted as emperor through some blunder, was shortly thereafter killed by the soldiers, as his excesses deserved.”

Palmyra had a "caravan economy" where "an oligarchical class of merchants and caravanners amassed considerable riches by exacting high tolls from caravans". The Palmyrene aristocracy lived in luxury and expended their wealth on fine buildings such as temples, colonnaded streets, palaces and fine tombs (Bounni 1985:382).

Palmyra was surrounded by fierce roving nomadic tribes. According to Hitti (1959:84):

"Palmyrene chiefs secured safe-conducts for passing caravans from desert sheikhs; guides led those caravans through the barren region; mounted archers protected them against bedouin raids; and the city imposed heavy duty on each article of merchandise as it passed through its gates".

Palmyra prospered exceedingly because of the tariff and tolls it levied on the traffic plying the caravan route between the Euphrates River and Damascus, as well as from the leases of municipal property and concessions. Tax farmers collected certain dues from the merchants under contract. There were precise customs regulations for the district and the number of 
denarii to be paid were specified for each item imported into Palmyra ${ }^{3}$ (Lewis \& Reinhold 1966:329-332).

Palmyra's enormous wealth basically lasted for a century and a half. Gibbon (in Lowe 1979:115) said of Palmyra that on account of its splendid "temples, palaces and porticoes of Grecian architecture”, it actually rivalled Rome.

The aristocracy of Palmyra set off their rank by eastern and western accoutrements. Portraits and tomb reliefs at Palmyra give an indication of what the people were like. Over linen tunics they wore woollen and cotton garments of vivid colours, with patterns and gold embroidery. Silks were worn that indicated the "love of the soft, gorgeous and intricate" that distinguished the rich Palmyrenes. Women often wore veils and jewellery was much in evidence. Everything was ornate and colourful and along the colonnades there were many statues of the honoured citizens who had contributed to the wealth and security of the city (MacMullen 1967:225).

\section{The geopolitical context of Palmyra}

Trade caravans that brought merchandise, especially luxury goods, from different countries, reached the Euphrates from the east, went on to the key city of Palmyra, and from there to Emesa, the coast or Antioch (Stoneman 1994:19). They had to traverse the Syrian desert in which nomads roamed, but this trade was a great source of wealth (Hitti 1959:15).

\section{Defence}

The Palmyrenes were a warlike people. Those who had Roman citizenship could join the Roman legions, otherwise Palmyrenes served as archers in the auxilia (Birley 1988:72). Palmyra's crack troops, the Archers, mounted bowmen who were used for desert patrol and caravan protection, as well as the army of the ruler, were one of its greatest assets. The Archers formed a prestigious association and "presided at feasts and festivals in honor of the god Bel” (MacMullen 1967:224).

The Rise of the Sassanids

After the demise of the Parthian Empire, the Persian Sassanids emerged as the new power in the east.

The Roman Empire of the third century AD was under siege from various sides. The Roman Emperor Valerian was captured by Persians outside Edessa in 259 AD and finally killed after a degrading imprisonment (Parker 1986:132). He was succeeded by his son Gallienus.

The Persian threat in the east made it possible for Arab power to advance as the Roman central government had difficulty in dealing with it. The Arabs were always competing for power. After the Nabataean kingdom came to an end, Palmyra was the dominant Arab state controlling the trade routes of the northern desert in Syria. Rome needed Palmyra to keep the Persians at bay. Odenathus' overtures to Persia had been rejected, with the result that he sided

This was a decree of the Palmyrene Senate of AD 137. 
with the Romans (Bowersock 1983:130). Under Gallienus it was the client state of Palmyra that finally expelled the Persian forces from the eastern provinces.

Kaizer (2002:263), in his review of Hartmann's book on Palmyra, states that it was shown that Palmyra had an "indispensable role...in securing Roman hegemony over the Eastern provinces" and that the "third-century crisis" which consisted of the decline in central authority, the Persian threat and the threat which the nomadic tribes posed to the caravan trade "paved the way for the gradual rise of Odaenathus and his circle", so that this ruler exercised power "formally legitimated by the supreme authority of the Roman emperor".

Kaizer (2002:263) calls Hartmann's work the "first monograph to grant Odenaethus, rather than his too often romanticized widow, pride of place."

\section{Roman Rule in the East}

"Had not Odaenathus, prince of the Palmyrenes, seized the imperial power after the capture of Valerian, when the strength of the Roman state was exhausted, all would have been lost in the East.” (HA Tryg. Tyr., 15.1)

Rome extended its influence over the ancient Near East because trade routes that passed through, brought luxury goods and made the countries on the periphery of the empire very wealthy. Roman society had become sybaritic, needing luxury goods such as spices (pepper and ginger, saffron, cloves and all kinds of seeds such as aniseed and poppy, and dry seasonings) and aromatics (myrrh and frankincense), pearls, ivory, tortoiseshell, balsam, dried fruit and roots. Incense was offered to the gods and used in Roman triumphs. Silk was also a highly valued commodity in Rome, and it constituted a conspicuous part of its wealth. It also formed the most important element of Palmyrene trade (Stoneman 1994:33-34).

When Zenobia succeeded Odenathus, she was not acceptable to the Romans as the successor of a client king. The Roman Empire could never be challenged by an ambitious ruler - especially a female one - without retaliating. But Zenobia had the advantage of a formidable and initially unconquerable army that Michalowski (1970:7) says had as its "backbone" troops who had always been formidable as opponents or allies of the Romans, the "renowned units of Palmyrene cameleers".

The HA (Tyr. Trig., 30. 11-12) quoted Aurelian, Claudius' successor, as maintaining that Zenobia had ruled well and that Emperor Claudius, while fighting the Goths, had acknowledged this:

"What of the Deified Claudius, that revered and honoured leader? For he, because he was busied with his campaigns against the Goths, suffered her, or so it is said, to hold the imperial power, doing it of purpose and wisely, in order that he himself, while she kept guard over the eastern frontier of the empire, might the more safely complete what he had taken in hand.”

By the late 260s, Zenobia became increasingly independent of Roman control. Zosimus (1.50) describes her territorial conquests at the time when Aurelian eventually decided to march against her:

"She controlled all Egypt and the East as far as Ancyra in Galatia; she would also have liked to take over Bithynia as far as Chalcedon, had the Bithynians not heard of Aurelian's elevation and shaken off Palmyrene control.” 
The Arabs

The Arab tribes, who were always jockeying for power, must have watched the rise of Odenathus with disquiet. They were independent, nomads and sedentary Arabs alike. Smaller social units formed a confederation known as the Tanukh (Bowersock 1983:132). The original homeland of the Tanukh was al-Qatif in the north-eastern part of the Arabian peninsula, but the Persian threat caused great emigration to desert regions west of the Euphrates (Bowersock 1983:132-133).

The Arabs' activities caused great tension during the rule of Odenathus and subsequently Zenobia. At the same time as Zenobia staged a revolt against Rome, she attacked the Arabs. She was said to have tricked the ruling sheik Jadhima, who came into conflict with her, by luring him to see her and cutting his veins so that he died (Bowersock 1983:132-133, n 45). Arab sources maintain that his successor, Amr ibn Adi, helped the Romans to conquer Palmyra and kill Zenobia. It was the war against the Arabs that started Zenobia's onward sweep to Egypt where she established herself as queen, and successor of Cleopatra (Bowersock 1983:134).

Zenobia, in her onslaught against the Arabian province, where her Arab enemies were increasing, destroyed the temple of Zeus Hammon at Bostra, which was the symbol of the city and the Roman legion there. This induced the Arabs to link up with Aurelian to ensure a victory over the powerful Palmyrenes (Bowersock 1983:136).

The Invasion of Egypt

When Zenobia struck at Egypt, she was threatening one of Rome's important lifelines, for Egypt was the breadbasket of the Mediterranean, an important source of corn for the Roman world. A scarcity of bread and famine caused unrest of enormous - even catastrophic proportions in the Roman world.

Zosimus (1.44) describes Zenobia's bid for power:

“Zenobia [now] became ambitious, and sent Zabdas to Egypt because Timagenes, an Egyptian who was working to hand Egypt over to the Palmyrenes, had raised an army of seventy thousand Palmyrenes, Syrians and barbarians, against whom were ranged fifty thousand Egyptians. In a fierce battle the Palmyrenes won a decisive victory, and after setting up a garrison of five thousand men, marched away.”

\section{A New Cleopatra}

Zenobia spoke Egyptian and was drawn to the Egyptian culture, but as Fraser (1999:109) and others emphasize, she was an Arab and inscriptions have given her the name Septimia Zenobia in Latin and Bat Zabbai in Aramaic. She was reputed to be as much an intellectual as Cleopatra VII of Egypt had been and under her rule the arts also flourished in her country. In a Palmyrene inscription she is called Septimia Bat-Zabbai as well as "daughter of Antiochus IV Epiphanes” who ruled Syria from 175-64 BC and whose wife had been Cleopatra Thea, the daughter of Ptolemy VI of Egypt (Stoneman 1994:112). Hence Zenobia's claim of Egyptian descent.

Julia Balbilla who visited the Memnoneia near Thebes in Egypt in AD 130 in the entourage of the Emperor Hadrian and his wife Sabina carved a poem on the northern statue 
that "spoke" at sunrise claiming that King Antiochus was her paternal grandfather while her maternal grandfather was Balbillus, prefect of Egypt (Rowlandson 1998:311). Both of the claimants - Balbilla and Zenobia - must have considered it politically beneficial to be associated with the rulers of Egypt and with the name of Antiochus. Stoneman (1994:112) avers that once Zenobia became "sole ruler of Palmyra she made much of this lineage."

According to Breton (2004:22) Zenobia was known to the Romans as Septimia Zenobia and she was set on proving that she had noble Roman or Palmyrene ancestors, especially Antiochus. However, this Antiochus is unknown ("cet Antiochus est inconnu”) but a claim to descend from the Seleucid king was supposed to legitimise her dynastic pretensions. Breton maintains that she probably only belonged to some important Palmyrene family.

HA (Tyr. Trig., 27.1) relates that Zenobia seized power when her sons Herennianus and Timolaus were still small. The writer's chauvinism comes to the fore when he says:

"Zenobia seized the imperial power, holding the government longer than was meet for a woman.”

Long (1997) maintains that the name Septimius/a used before the Palmyrene names of members of Zenobia's and Vaballathus's family was because they "received Roman citizenship from [Septimius] Severus" (the husband of the Syrian Julia Domna) and that this proves that "that the family dominated Palmyrene affairs by the 190s."

HA (Tyr. Trig., 27.1) alleges that Zenobia emulated the famous queens Semiramis and Dido $^{4}$. Her so-called claim quae se de Cleopatrarum Ptolemaeorumque gente iactret (HA Tyr. Trig., 30. 2) ("boasting herself to be of the Cleopatras and the Ptolemies") is called a “fiction” (Magie 1932:135, note 2).

Long (1997) maintains that Zenobia's claim to be descended from the Ptolemies "would seem a wild fantasy of the Historia Augusta, but for the fact that Kallinikos of Petra, who flourished during the reign of Gallienus, addressed a ten-book history of Alexandria 'to Cleopatra': Zenobia is the only possible dedicatee." 5

Long (1997) points out that "the identification may also relate to use of the Hellenistic name Antiochus for Zenobia’s father, even in Palmyrene inscriptions.” 6

\section{Promotor of Graeco-Roman Culture}

In Palmyra Zenobia presented herself as a Hellenistic queen, assiduously cultivating intellectualism in emulation of Julia Domna, the earlier empress from Syria, wife of Septimius Severus, and her sister, Julia Mammaea (Bowersock 1983:135).

In "the temple of Jupiter Capitolinus in the capital city of the Arsinoite nome" in Egypt, Julia Domna was emulated as "our lady Julia Domna...'mother of the invincible camps"” (Rowlandson 1998:45, Excerpt from BGU II 362, Ptolemais Euergetis AD 215).

Stoneman (1994:131) also avers that Zenobia had Julia Domna's famous coterie of artists and intellectuals in mind as she

$4 \quad$ Semiramis was a legendary Assyrian queen and Dido was queen of Carthage.

$5 \quad H A$ Tyr. Trig. 27.1, 30.2; Claud. 1.1; cf. Tyr. Trig. 30.19, Aurel. 27.3, Prob. 9.5. Arthur Stein, "Kallinikos von Petrai,” Hermes 58 (1923) 448-56.[Long's reference].

6 Eugenia Equini Schneider, Septimia Zenobia Sebaste, Studia archaeologica 61 (Rome: “L'erma” di Bretschneider 1992) 21-23. [Long’s reference]. 
"gathered around her a glittering firmament of Greek men of letters, chief among them Philostratus, author of Lives of his contemporary philosophers and of the wonder worker Apollonius of Tyana.”

Unfortunately Zenobia's coterie could not equal the “pool of talent” available to Julia Domna a century previously. One outstanding achievement, however, was that the Neoplatonic school of the wealthy city of Apamea was founded by Amelius, apparently with Zenobia's support and the philosopher Cassius Longinus' approval (Stoneman 1994:132).

Zenobia is said to have received instruction of a high quality from Longinus, who taught her Greek letters before he was killed by Aurelian for supposedly being a bad adviser to the queen as seen in the biography written about the Deified Aurelian (Divus Aurelianus), attributed to "Flavius Vopiscus of Syracuse" (HA A., 30.3). In a footnote to HA A., 30. 4-5 Magie describes Longinus is described as a "Neo-Platonist philosopher, rhetorician and philologian” who had pursued a career in Athens . At the high age of nearly sixty he was called to Zenobia's court (Stoneman 1994:130).

Stoneman (1994:133) maintains that it was unusual for Palmyra to have attracted the "Greek-trained intellectuals of western Syria, whose natural home was the Hellenic West". Even before the destruction of the city some intellectuals went from Palmyra to the West and there were others with the Palmyrene name Odenathus who gained prominence. These facts indicate that Palmyra had "power and prestige" beyond its territory. After the destruction of the city many others "found employment in other parts of the Roman empire" (Stoneman 1994:133).

Arab Hellenism was the order of the day in the Near East. In old Nabataean Petra, Hellenic culture also flourished. As mentioned previously, Callinicus, a sophist from Petra, presented a ten-volume history of the Egyptian city of Alexandria to Zenobia, once she had conquered Egypt (Bowersock 1983:135).

Stoneman (1994:151) deals with Paul of Samosata, the bishop of Antioch, as one of the so-called "fugitive intellectuals" at Zenobia's court Samosata, a town north of Edessa, was not Hellenic in character and in fact the new thinkers disliked Hellenic idolatry. Paul wore Oriental clothes and spoke Syriac before leaving for the Hellenic world and becoming influential in Antioch. His behaviour there was condemned by Eusebius, who alleged that Paul preferred to be known as ducenarius rather than bishop, as he was also procurator ducenarius of Antioch, i.e. an imperial financial officer. Apparently Zenobia was his patron. John Chrysostom alleged that she had Jewish sympathies which Paul encouraged (Stoneman 1994:150). He was Zenobia's viceroy in Antioch until Aurelian deposed him as one of her supporters in 272 AD. Christianity only became properly established in Syriac-speaking Antioch sixty years after Zenobia’s reign (Stoneman 1994:151).

According to Millar (1971:5) Palmyra was a Roman colonia in Paul's time and officially bilingual in Palmyrene and Greek. He (1971:13) maintains that in the third century the "Near East is fraught with ambiguities".

"There is fairly substantial evidence for a Jewish community in Palmyra. Her [Zenobia's] possible favour to Judaism combined with the nature of Paul's doctrines may explain how the story of their connection arose. But we can also discount the version of Theodoret and Chrystostom, that the desire to please Zenobia was the cause of Paul's lapse into heresy.” 
He (1971:17) calls this a myth, a hostile fiction and says:

"we can confidently dismiss from the history books the monstrous figure of 'Paul of Samosata' the ducenarius of Zenobia'; we can see that we do not necessarily need to look to the expansion of Palmyrene power in order to explain why the orthodox party in Antioch could appeal to a pagan Emperor.”

Zenobia - the woman vs. the myth

Zenobia was born in Palmyra in approximately 241 AD. Her father was Julius Aurelius Zenobios (or Zabdilas in Armenian), one of the two generals of Palmyra in 242/3 AD. Her marriage to the powerful Septimius Odenathus made her an important role-player in Palmyra (Stoneman 1994:115).

Zenobia was magnificent to look at:

"Her face was dark and of a swarthy hue, her eyes were black and powerful beyond the usual wont, her spirit divinely great, and her beauty incredible. So white were her teeth that many thought she had pearls instead of teeth.” (HA Tyr. Trig., 30. 15)

The writer eulogises her vox clara et virilis (HA Tyr. Trig., 30. 16), i.e. her clear and masculine voice. She is also described as "stern”, "clement”, "prudent” and "hardy" (HA Tyr. Trig., 30. 16). Another male attribute that this remarkable woman apparently had was that she could hold her own when drinking with her generals, and with Persians and Armenians, but she did this (HA Tyr. Trig., 30. 18):

"only for the purpose of getting the better of them."

Chastity was said to be one of Zenobia’s main attributes (HA Tyr. Trig., 30. 12):

"Such was her continence, it is said, that she would not know even her own husband save for the purpose of conception. For when once she had lain with him, she would refrain until the time of menstruation to see if she were pregnant; if not, she would again grant him an opportunity of begetting children.”

So, not only was Zenobia a hunter, a soldier, and vigorous of mind, but her supposed chastity had to prove that she was also a rare exception to the rule that Oriental women were reputedly lax and voluptuous. Chastity with regard to procreation is regarded as a virtue in Judaeo-Christian thought. Unlike Cleopatra VII whom she so proudly claimed as her ancestor, there was no breath of scandal about Zenobia. In the case of Cleopatra, however, much of the scandal had undoubtedly been fabricated for political reasons.

If, on the one hand, Zenobia was purported to be abstemious and conservative, she showed on the other hand that she had a sybaritic side. She appears to have been extraordinarily luxury-loving and ostentatious, but these were qualities ascribed to Orientals. We are given a glimpse of her life-style:

"She lived in regal pomp. It was rather in the manner of the Persian kings that she banqueted; but it was in the manner of a Roman emperor that she came forth to public assemblies, wearing a helmet and girt with a purple fillet, which had gems hanging from the lower edge, while its centre was fastened with the jewel called cochlis, used 
instead of the brooch worn by women, and her arms were frequently bare.” (HA Tyr. Trig., 30. 13-14)

Although Zenobia apparently spoke Latin poorly she knew Egyptian well (HA Tyr. Trig., 30. 21) and was knowledgeable about history (HA Tyr. Trig., 30. 22):

"In the history of Alexandria and the Orient she was so well-versed that she even composed an epitome, so it is said; Roman history, however, she read in Greek.”

The HA (Tyr. Trig., 15. 8) praises Odenathus as a great warrior and hunter but he stresses that Zenobia was her husband's equal in manly pursuits and a paragon among women:

"his wife, too, was inured to hardship and in the opinion of many was held to be more brave than her husband, being, indeed, the noblest of all the women of the East, and...the most beautiful."

In the HA "Flavius Vopiscus" calls her "that most powerful woman" (A 28.2) Stoneman (1994:115) maintains that while Odenathus was "cautious" and did not neglect his obligations to Rome, Zenobia was rather more ambitious, a Lady Macbeth, who would connive at obtaining power, also because her own son's succession had to be ensured. Beard (1973:292) avers that Zenobia was not an "arm-chair strategist" but a soldier and she loved "power and strife", so that she rose up against the "overweening military power of imperial Rome" as Cleopatra VII of Egypt, the partner of Julius Caesar and Mark Antony, had done to save her realm.

Drinkwater (1994:57) disagrees with the Zenobia eulogy of an author like Stoneman, which is mostly gleaned from the $H A$, maintaining that her threat to the Roman Empire was exaggerated. Stoneman, he says:

"ignores the immensely strong centripetal tendencies that were a major strength of the Roman imperial system: if Zenobia had defeated Aurelian she would have become responsible for the administration and protection of the whole empire.”

Drinkwater (1994:57) criticises Stoneman for drawing "unashamedly" on the "Historia Augusta, Arabic myth and history" which is of little use to the "serious historian". He (Drinkwater 1994:57) also challenges Stoneman's allegation that Zenobia created a "third empire” besides those of Rome and the Sassanids. In his review (1994:57) of G. Fowden's book Empire to Commonwealth: Consequences of Monotheism in Late Antiquity Drinkwater says that Fowden understands the political imperatives of the region better than Stoneman for "mastery of the Middel East as a whole is possible only through control of both the eastern Mediterranean and the Iranian Plateau, via the Fertile Crescent.”

Fowden (1999:80) argues that Palmyra could not be "autonomous" for the following reason:

"the Palmyrenes' brief independence in the late 260s and early 270s...was doomed because they neither took to the eastern sea nor scaled the Zagros.”

He (1999:80) also alleges that the third-century Sassanids did not intend to obtain a "worldempire”. 
Magie (1932:135, note 1) denies that Zenobia had sons called Herennianus and Timolaus but as the Prosopography of the Later Roman Empire (1971) puts it she was:

"Mother of L. Iulius Aurelius Septimius Vaballathus Athenodorus IGR III 1027-8, V. Aur. 38. and of Septimius Antiochus IGR III 1029 (her sons are called Herennianus and Timolaus SHA, V.Gall. 13.2, V. Trig Tyr.15.2...)”

Her son was named Vaballathus Athenodorus, who succeeded his father in 266-267 AD and who "reigned jointly with Zenobia" (Magie 1932:130, note 2). According to Stoneman (1994:114) Zenobia gave birth after her marriage to a son called "Wahballath, gift of Allat, or in Greek, Athenodorus”. The existence of Wahballath - or Vaballathus - is proven on coins minted after the death of his father.

\section{Zenobia's Overthrow}

L. Domitius Aurelianus, a formidable general, called "Restitutor orbis", turned out to be the nemesis of Zenobia in the east, thwarting her imperial ambitions. Her run of success, spectacular though it had been, was dramatically challenged (Stoneman 1994:164). Zenobia had, by the time she encountered Aurelian, come to control the commercial and trade routes vital to Rome, including the corn from Egypt, the Bosphorus and those to Abyssinia, India and Arabia (Fraser 1999:118).

Aurelian was a native of Illyricum (Yugoslavia and Hungary) nicknamed by his men "Hand-on-Hilt" for his precipitate action in punishing opponents of the Empire. Liberal culture was not his strong point but he came from hardy stock, seasoned in farm and camp, who lived and died hard. Aurelian was cruel and in fact alien to Rome although he had to be Rome’s salvation (MacMullen 1967:226).

It is assumed that Aurelian left Rome in $271 \mathrm{AD}$ and that he was ultimately able to besiege Palmyra in 272 AD (Stoneman 1994:165). It took four months of marching to reach Antioch. Zosimus (1.50-51) describes this battle as follows:

"Aurelian found Zenobia well prepared with a large army...Seeing however, that the Palmyrene cavalry felt very confident of its heavy, strong armour and also greatly surpassed his own in horsemanship, he set his infantry apart somewhere over the Orontes River, and ordered the Roman horse not to engage the fresh Palmyrene cavalry immediately, but to take their charge and pretend to flee until they saw that both their pursuers and their horses were abandoning the chase, exhausted by the heat, and the weight of their armour. This is exactly what happened. The emperor's cavalry obeyed his order, and when they saw the enemy giving up...wheeled and charged, trampling them as they fell from their mounts. The slaughter was varied...”

Aurelian had won the day through a ruse. The survivors fled towards the city of Antioch.

The Palmyrene general, Zabdas, paraded a man who looked like Aurelian in the city, in case the inhabitants turned on the Palmyrenes. Then Zabdas slipped out with Zenobia and the "remnants of his army" and fled to Emesa. Antioch did not oppose Aurelian's entry although the troops of the "priest kings of the city had thrown in their lot with Zenobia" (Zos 1.53). At the next city, Emesa, the Palmyrenes suffered another terrible defeat. So Aurelian entered this 
city as well and captured Zenobia's treasure while she retreated to Palmyra. The next stage was the conquest of Palmyra (Zos. 1.54):

"which on his arrival he encircled and besieged, securing an abundance of provisions from the nearby peoples".

Zenobia prepared Palmyra for a siege by building a circuit wall and posting patrols and sentries. Apparently it was summer with attendant discomfort and a hot southerly wind. Zosimus (1.54) says that the Palmyrenes "jeered at the Romans, considering their city impregnable” but the Romans’ persistent siege brought the Palmyrenes great suffering due to lack of food.

"Flavius Vopiscus” (HA A 26.3-5) mentions a letter from Aurelian to one "Mucapor", that reveals how formidable an opponent the Palmyrene queen was in a desperate situation:

"The Romans are saying that I am merely waging a war with a woman, just as if Zenobia alone and with her forces only were fighting against me, and yet, as a matter of fact, there is as great a force of the enemy as if I had to make war against a man, while she, because of her fear and sense of guilt, is a much baser foe... She fears like a woman, and fights as one who fears punishment."

At last, when the siege of Palmyra had lasted for some time, he made her an offer because he was “exhausted and worn out by ill-success” (HA A 26.6 ):

"For I bid you surrender, promising that your lives shall be spared, and with the condition that you, Zenobia, together with your children shall dwell wherever I, acting in accordance with the wish of the most noble senate, shall appoint a place.”

Although her treasures would be forfeit to Rome, Aurelian would extend mercy to her people. According to the HA (A 27.5), supposedly from a collection of letters made by one Nicomachus, the response Aurelian received was an insolent letter from Zenobia, who called herself regina orientis (HA A 27. 2) ("Queen of the East”). She would not surrender, she would fight, and she would prefer to die a queen as Cleopatra had done. She claimed that Saracens, Armenians and brigands of Syria were on her side:

"If those forces then, which we are expecting from every side, shall arrive, you will, of a surety, lay aside that arrogance with which you now command my surrender, as though victorious on every side.”

Aurelian was enraged and cut off Persian reinforcements, seducing the Saracens and Armenians to his own side. Major tribal migrations had taken place here and the nomads were natural enemies of Zenobia. They therefore allied with Rome in the destruction of Palmyra in 272/3 AD (Bowersock 1983:131-134).

The Armenians' desertion to the Roman side, was a last great blow to the battered Palmyrenes and this induced Zenobia's desperate flight. The $H A$ ( $A$ 30) tells how she stole away on fleet dromedaries to the Persians, but she was held up at the Euphrates River, which enabled her Roman pursuers to catch up and capture her. With their queen in his hands, the Palmyrenes capitulated to Aurelian. He took the city in peace and installed the prefect of Mesopotamia, Marcellinus, as commander, as well as "one Sandarion” with a "garrison of six hundred archers” (Stoneman 1994:177). 
Zenobia, her general Zabdas, the philosopher Longinus and other leading men of her court, were taken to Emesa to stand trial. Zosimus (1.56) describes what transpired:

"In the course of pleading her defence, she involved many others on the ground that they had misled her since she was a woman."

The Romans took extremely valuable booty, which is an indication of how wealthy Palmyra - and Zenobia - was (HA A 28. 5):

"Then were brought in those garments, encrusted with jewels, which we now see in the Temple of the Sun, then, too, the Persian dragon-flags and head-dresses, and a species of purple such as no nation ever afterward offered or the Roman world beheld.”

The HA (A 30) maintains that the Roman soldiers demanded that Zenobia be put to death:

"Aurelian, however, deeming it improper that a woman should be put to death killed many who had advised her to begin and prepare and wage the war, but the woman he saved for his triumph, wishing to show her to the eyes of the Roman people.”

"Flavius Vopiscus" deplored the execution of Longinus the philosopher, Zenobia's teacher of Greek, because Aurelian was told that he was the one who had advised Zenobia to send her insolent and defiant letter ( $H A$ A 30). In a complete about-face, Zenobia blamed her past actions on the bad advice she had received from masculine advisers. This was either an act of guile or else she displayed an uncharacteristic fear of reprisal. Her reputed fortitude had, in fact, been overruled by her instinct for survival.

Those she accused paid a heavy price (Fraser 1999:124). Zosimus (1.56) praised Longinus for bearing it "so nobly that he comforted those who were indignant at his fate". Zenobia, so brave in the field, chose to seem weak when it suited her. Gibbon (in Lowe 1979:116-117), condemned her in chauvinistic terms:

"But as female fortitude is commonly artificial, so it is seldom steady or consistent."

Aurelian made it clear that he held Zenobia in high esteem in a letter that Aurelian ("the bravest of men": vir fortissimus (HA Tyr. Trig., 30. 4)) had sent to the Senate and Romans in which he had defended himself against the shame of fighting a woman:

"I have heard, Conscript Fathers, that men are reproaching me for having performed an unmanly deed in leading Zenobia in triumph. But in truth those very persons who find fault with me now would accord me praise in abundance, did they but know what manner of woman she is, how wise in counsels, how steadfast in plans, how firm toward the soldiers, how generous when necessity calls, and how stern when discipline demands. I might even say that it was her doing that Odaenathus defeated the Persians, and, after putting Sapor to flight, advanced at the way to Ctesiphon. I might add thereto that such was the fear that this woman inspired in the peoples of the East and also the Egyptians, that neither Arabs nor Saracens nor Armenians ever moved against her. Nor would I have spared her life, had I not known that she did a great service to the Roman state when she preserved the imperial power in the East for herself, or for her children.”

As Zenobia was considered a barbarian queen who somehow had managed to shame the Romans by defeating them, her "credentials" had to be established so that Romans could 
respect her. Also the "ennobling" was intended to disparage the emperor who could not vanquish her and praise the one who did (Fantham et al. (1994:389), author of chapter not cited).

Zosimus (1.59) alleges:

"It is said, however, that Zenobia died either from disease or by refusing to eat, and that all the others, save her son, were drowned in the crossing from Chalcedon to Byzantium”.

He may have been trying to liken her to Cleopatra who had preferred to take her own life rather than be humiliated by the Romans and made to walk in a triumph as the emperor's captive. Aurelian, however, displayed Zenobia as a great prize (HA Tyr. Trig., 30. 24-26):

with golden fetters, and even on her neck she wore a chain of gold, the weight of which was borne by a Persian buffoon.”

The HA (A 33, 34) also describes this "most brilliant” (speciosissimus) triumph. Out of the three royal chariots, two were Palmyrene, one had belonged to Odenathus and one Zenobia had caused to be made so that she could one day use it to visit Rome. There were gladiatorum paria octingenta, praeter captivos gentium barbararum (HA A 33. 4) ("eight hundred pairs of gladiators besides the captives from the barbarian tribes".) Animals in the triumph included twenty elephants and two hundred beasts from conquered lands, such as giraffes and elks.

\section{Zenobia in Rome}

After Aurelian had subdued the East and returned to Europe, taking Zenobia with him, the Palmyrenes rebelled and killed the garrison commander Sandario. Aurelian retaliated viciously. He returned and destroyed the city, only extending mercy after many of its inhabitants had been killed (HA Tyr. Trig., 31. 10).

Although Aurelian is described by "Flavius Vopiscus" as severus, truculentus, sanguinarius...princeps (HA A 36. 3) (“a stern, a savage, and a blood-thirsty prince”), he spared Zenobia’s life. "Trebellius Pollio" also describes the outcome of her imperial venture (HA Tyr. Trig., 30. 27):

"Her life was granted her by Aurelian, and they say that thereafter she lived with her children in the manner of a Roman matron on an estate that had been presented to her at Tibur, which even to this day is still called Zenobia, not far from the palace of Hadrian or from that place which bears the name of Concha."

Gibbon (in Lowe 1979:19) describes Zenobia’s retirement as a metamorphosis from a warrior queen into a Roman matron who married her daughters into noble families and whose race survived until the fifth century. She was one of the "usurpers" who had not been strangled after the pomp of the emperor's triumph, but who were permitted to live out their lives honourably and in affluence. 


\section{Conclusion}

With Zenobia gone, Palmyra was lost, its golden age terminated. The Romans destroyed the magnificence and looted the treasures. The kingdom was dissolved and the city left in ruins. The Palmyrenes were either killed or scattered.

So remarkable had been the martial queen's stand against the mighty Roman Empire and so tragic her fall, that she remains an unforgettable character. Zenobia is a Syrian heroine to this day, and her image appears on Syrian banknotes.

Zenobia must have been either extremely reckless, desperately courageous, or simply incurably power hungry to take on the Romans. This great Oriental queen was renowned for mainly four attributes, viz. her beauty, her courage in battle, her remarkable virtue and the tragic outcome of her clash with Rome. In addition she was a sensible and dynamic ruler, setting a fine example to her people and perhaps also to the women of her time.

Hughes-Hallett (1990:15) says with regard to prominent women of antiquity such as Cleopatra VII of Egypt and Zenobia that even in their lifetimes they were subject to "the two overlapping chauvinisms of race and sex". Despite Roman prejudice against foreigners and especially women, Zenobia earned their grudging respect.

Outstanding women have emerged time and again throughout history, and she certainly is one.

\section{BIBLIOGRAPHY}

Beard, M R 1973. Women as Force in History: A Study in Traditions and Realities. New York: Collier Books.

Birley, A 1988. The African Emperor: Septimius Severus. London: BT Batsford Ltd.

Bowersock, G W 1983. Roman Arabia. Cambridge, Massachusetts: Harvard University Press.

Braund, D 1984. Rome and the Friendly King: The Character of the Client Kingship. London \& Canberra: Croom Helm.

Bounni, A 1985. "Palmyra: the Caravan City". In Weiss, H (ed) Ebla to Damascus: Art and archaeology of ancient Syria.. Washington, D.C.: Smithsonian Institution Traveling Exhibition Service: 380-385.

Breton, J-F 2004. “Zénobie, reine de Palmyre”. In Histoire Antique 15:20-26.

Colledge, M A R 1976. The Art of Palmyra. London. Westview Press.

Drinkwater, J F 1994. Review of R. Stoneman, Palmyra and Its Empire: Zenobia's Revolt Against Rome, University of Michigan Press in History Today 44(9):57.

Drinkwater, J F 1994. Review of G Fowden, Empire to Commonwealth: Consequences of Monotheism in Late Antiquity, Princeton University Press in History Today 44(9):57.

Drinkwater, J F 2002. Review of A Watson. Aurelian and the Third Century. London and New York: Routledge, 1999. In Journal of Roman Studies 92:261-263.

Fantham, E et al. 1994. Women in the Classical World. New York: Oxford University Press.

Fortin, M 1999. (trans. McCauley, J) Syria : Land of Civilizations. Quebec : Musée de la Civilisation. Fraser, Antonia 1999. Boadicea's Chariot: The Warrior Queens. London: Arrow Books.

Gibbon, E. 1979. The Decline and Fall of the Roman Empire. (Abridgement by Lowe, D M). London: Book Club Associates.

Grant, M 1981. History of Rome. Fakenham, Norfolk: Fakenham Press Ltd.

Hitti, P K 1959. Syria: A Short History. London: Macmillan.

Hitti, P K 1970. History of the Arabs. 9th Edition. London: Macmillan.

Hughes-Hallett, L 1990. Cleopatra: Histories, Dreams and Distortions. London: Pimlico.

Kaizer, T. 2002. Review of U. Hartmann, Das Palmyrenische Teilreich, Oriens und Occidens 2. Stuttgart: Steiner, 2001. Journal of Roman Studies 2:263. 
Lewis, N \& Reinholdt, M 1966. Roman Civilization Sourcebook 2, The Empire. New York: Harper \& Row.

Lowe, D M 1979. Abridgement of Edward Gibbon's The Decline and Fall of the Roman Empire. London: Book Club Associates.

MacMullen, R 1967. Enemies of the Roman Order: treason, unrest and alienation in the Empire. Cambridge Mass.: Harvard University Press.

Michalowski, K 1970. Palmyra. London.

Millar, F 1971. "Paul of Samosata, Zenobia and Aurelian: The Church, Local Culture and Political Allegiance in Third-Century Syria”. In Journal of Roman Studies 61:5-17.

Parker, H M D 1986. History of the Roman World from AD 138 to 337. London: Methuen.

Rowlandson, J (ed) 1998. Women and Society in Greek and Roman Egypt. Cambridge: Cambridge University Press.

Starr, C G 1991. The Roman Empire 27 BC -AD 476: A Study in Survival. Oxford: Oxford University Press.

Stoneman, R 1994. Palmyra and its Empire: Zenobia's Revolt Against Rome. Ann Arbor: University of Michigan Press (first paperback edition 1994).

Syme, R, Sir 1983. Historia Augusta Papers/Ronald Syme. Oxford Clarendon Press.

Ziadeh, N 1968. Syria and Lebanon. Beirut: Librairie du Liban.

Ancient sources

Historia Augusta (Volumes I to III). Magie, David (trans.) 1932. London: William Heinemann.

Zosimus: A New History. Ridley, Ronald T (trans.) 1982. Canberra: Australian Association for Byzantine Studies.

Internet

Long, J F 1997. Vaballathus and Zenobia. www.roman-emperors.org/De imperatoribus Romanis. 